\title{
Iran's ballistic missile program and its foreign and security policy towards the United States under the Trump Administration
}

\author{
El programa de misiles balísticos de Irán y su politica exterior y de seguridad \\ hacia los Estados Unidos bajo la Administración Trump
}

\author{
MOHAMMAD ESLAMI \\ Research Centre for Political Science (CICP), University of Minho (Portugal)
}

\section{Cómo citar/Citation}

Eslami, M. (2021). Iran's ballistic missile program and its foreign and security policy towards the United States under the Trump Administration. Revista Española de Ciencia Política, 55, 37-62. Doi: https://doi.org/10.21308/recp.55.02

\begin{abstract}
Drawing on the Strategic Culture Theory, this article analyzes Iran's evolving ballistic missile program (BMP), by focusing especially on the period of the Trump administration (January 2017-January 2021), including both Iran's Islamic Revolutionary Guard Corps (IRGC) shooting down a US surveillance drone in the Strait of Hormuz in June 2019 and Iran's attack on the US military bases following the assassination of IRGC General Qasem Soleimani, in January 2020. This work demonstrates the increasing reliance on the 'revolutionary', more offensive narrative, which has become additionally reinforced after the assassination of General Qasem Soleimani and Professor Mohsen Fakhrizadeh. This has consolidated the retaliatory aspects in Iran's foreign and security policy, while it has also marginalized moderated actors willing to engage in negotiations with the US.
\end{abstract}

Keywords: Iran, strategic culture, ballistic missile, JCPOA, Qasem Soleimani, military doctrine

\section{Resumen}

Basándose en la teoría de la cultura estratégica, este artículo analiza el programa de misiles balísticos (BMP) en evolución de Irán, centrándose especialmente en el período de la Administración Trump (enero de 2017-enero de 2021), incluidos el derribo de un dron de vigilancia estadounidense en el estrecho de Ormuz por parte del Cuerpo de la Guardia Revolucionaria Islámica de Irán (IRGC) en junio de 2019 y el ataque de Irán a las bases militares estadounidenses tras el asesinato del general del IRGC, Qasem Soleimani, en enero de 2020. Este trabajo 
demuestra la creciente confianza en la narrativa revolucionaria más ofensiva, que se ha visto reforzada adicionalmente tras el asesinato del general Qasem Soleimani y del profesor Mohsen Fakhrizadeh. Esto ha consolidado los aspectos de represalia en la política exterior y de seguridad de Irán, al tiempo que ha marginado a los actores moderados dispuestos a entablar negociaciones con Estados Unidos.

Palabras clave: Irán, cultura estratégica, misil balístico, PAIC, Qasem Soleimani, doctrina militar.

\section{INTRODUCTION}

The expansion of Iran's missile program after 2005 has contributed to the volatility in the Middle East region. While Iran's military and financial support to Hezbollah and other paramilitary groups fighting Israel has been moving the US toward confrontation with Iran (Perthes, 2010; Pompeo, 2018), Saudi Arabia - Iran's main political rival in the region- received comprehensive support from Donald Trump. What followed were the attacks by Iran-supported Houthis movement in Yemen (including their equipment with missiles and advanced weapons), at airports and Saudi Arabia's and the United Arab Emirates (UAE)'s oil companies. The regional situation exacerbated especially in May 2019, after five oil ships were attacked at the Fujairah port of UAE and a hybrid attack (with missile and military drones) on Aramco — the world's biggest oil company in Saudi Arabia— in September 2019. ${ }^{1}$

In addition, Iran's position has become less pro-cooperative following US withdrawal from the Joint Comprehensive Plan of Action (JCPOA), new sanctions and most importantly, the assassination of General Qasem Soleimani. In mid-2019, Iran declared its intention to breach the 3.67 percent uranium enrichment limit stipulated in the agreement, while it also admitted to have exceeded the negotiated limits on uranium enrichment but did not threatened to reach weapons-grade level. Moreover, following the assassination of Iranian nuclear scientist Professor Mohsen Fakhrizadeh in late 2020, Iran took steps to decrease its commitments under the JCPOA, including the use of new centrifuges, renovation of Arak reactor and the 20 percent uranium enrichment. In this connection, Iran's officials declared that the country "will produce 8-9 kilogram 20 percent Uranium every month"2, while it was also stated that the country was ready to enrich the uranium "even above 20 percent, if needed" 3 .

1. The US and Saudi Arabia claimed that the attack was arranged by Iran. However, Iran called it a fake scenario.

2. Salehi, A. 2021. "Iran will produce 8-9 kilogram 20 percent Uranium monthly", Islamic Republic News Agency (Irna), January 6 ${ }^{\text {th }}$. Available at: https://www.irna.ir/news/83365317/ (accessed: January $6^{\text {th }}, 2021$ ).

3. Kamalvandi, B. 2021. "Iran will enrich its Uranium even above 20 percent if needed", Mehr. Available at: https://www.mehrnews.com/ (accessed: January $\left.05^{\text {th }}, 2021\right)$. 
In the meanwhile, the 2020 US presidential election raised high expectations in Iran, especially because of the green light for returning to the negotiation table [for a round of negotiations beyond nuclear program and JCPOA] was shown by Joe Biden, that led to the President Rouhani's statement that "the negotiation's doors are always open" and "if the US repents, we would accept" uncompromising reaction by the Head of Air-Space forces of IRGC, who stated that the missile program is Tehran's "red line" adding that "no one shouldn't even dare to hold negotiation in this regard." He emphasized that "no official is allowed to negotiate about [Iran's] missile capability" . This is one of the most offensive statements articulated by IRGC officials to the government throughout the history of the Islamic revolution in Iran.

Except for the nuclear steps Iran took after the assassination of Soleimani and Fakhrizadeh, the development, testing and employment of long-range ballistic missiles in Iran grew extremely fast. There are only four instances when Iran employed its Ballistic Missile Program (BMP) for the military means after Iran-Iraq war; and all of them occurred during the Trump era, namely: a) the IRGC attack on the ISIS's base and headquarters in the Syrian province of Deir al-Zour in June 2017, in response to the terrorist attack perpetrated by ISIS on Iran's Parliament; b) a retaliatory attack at the ISIS bases in the Eastern Euphrates in Syria in October 2018; c) the shooting down of the largest and most advanced US UCAVs, Global Hawk RQ4, by Iran's air defense system in June 2019; and d) an attack on the two US military bases of Ain Al-Asad and Al-Taji in retaliation for the assassination of IRGC General Qasem Soleimani in January 2020.

This article explores Iran's perspective on its ballistic missile program (BMP), by drawing on the Strategic Culture Theory (SCT) which pays special attention to non-material, internal factors as they shape the state elites' identity as well as the population of the country, thus allowing to understand the reasons behind the course of foreign policies undertaken by individual countries (Gray, 1999). Historical experiences and the unique language associated with the acquisition, production or testing and military employment of ballistic missiles are viewed as "culturally endowed ways" (Kartchner and Johnson, 2009) which define the costs and benefits of a particular decision, creating its own, particular rationality (Eslami and Vieira, 2021). According to Meyer, this "allows to map a corridor of 'normal' or 'probable' behavior of states and integrate them into more comprehensive analyses of strategic choice" (2005: 528).

Against the background of the current state of the art, three individual dimensions of Iran's strategic culture are distinguished here: First, deterrence which draws upon preserving territorial integrity, self-sufficiency and independence. Second,

4. Rouhani, H. 2021. “The doors for negotiations are always open”, Irna. Available at: https:// www.irna.ir/news/ (accessed: January $05^{\text {th }}, 2021$ )

5. Hajizadeh, A. 2021. "Nobody dares to negotiate on BMP", Deutsche Welle. Available at: https://www.dw.com/fa-af/ (accessed: January $05^{\text {th }}$, 2021) 
fighting global arrogance which includes anti-imperialism, support for the mostazafin, and anti-Zionism. And third, skepticism about international cooperation, which produces a de-facto-prohibition of any negotiation about BMP. The application of these elements of the Strategic Culture Theory to Iran suggests that several aspects of the history of the country including the role of ancient civilizations and Mongol invasions, identity and religion are often intertwined and mutually reinforcing (Stanley, 2006; Thaler et al., 2010). First of all, contributions highlight Shi'ism as a determining set of norms and values that defines most of its foreign policy (Cain, 2002; Stanley, 2006; Knepper, 2008; Haynes, 2008; Barzegar, 2010). This "trait" is informed by concepts of Islam and the Sharia law, the principles and rules of morality, as well as jurisprudence (Salehian, 2018). Importantly, the later has a number of guidelines about how to use warfare, including the prohibition of mass destruction weapons (Smith, 2012; Eslami and Vieira, 2021). However, another key feature of the Shia religion identified as Iran's strategic culture is deterrence that allows for both, strikes to prevent enemy attacks and a war on the aggressor's soil (Giles, 2003; Taremi, 2014). Contributions have also identified ideology (Strain, 1996; Stanley 2006; Taremi 2014,), in the sense of a very fixed set of views of Iran's leadership (e.g., Iran's representation as a victim of the Western imperialism), as a key component of Iran's strategic culture (Adib-Moghaddam, 2005; Eisenstadt, 2015; Ostovar, 2016; Kinch, 2016).

Contrary to the ongoing research on the strategic culture of other countries (Lantis, 2002; Larsen and Johnson, 2006; Kartchner and Johnson 2009), contributions on Iran have been rare, especially when it comes to its foreign policy after 1979 . While there is research applying the SCT on Iran's nuclear program (Cain 2002; Knepper, 2008), SCT-informed analysis of Iran's ballistic missile program is unaccustomed. With an aim to understand how strategic culture has shaped Iran's foreign and security policy towards the US under Trump administration and to establish a link to the vast literature on Iran's foreign policy (Adib-Moghaddam; 2005; Przeczek, 2013; Mazaheri, 2013; Katzman, 2015, 2017; Ansari, 2016), this article analyzes the evolution of Iran's policy towards the BMP; and it does so by drawing on the continuum constituted by two main narratives: the "revolutionary" narrative and "moderation" one (Eslami and Vieira, 2021).

It will be argued that Iran has adopted a more offensive security policy towards the US under the Trump administration. This change is reflected in discourses by Iranian officials. It is important to take into consideration that the revival of the "revolutionary" narrative has established a more direct correspondence between the dominant narrative and Iran's strategic culture, while it has also reinforced the already central role of BMP in the latter (id.). It is, thus, important to investigate how the aforementioned shift has taken place. This is precisely the present article's endeavor. While drawing on Iran's official strategic documents including military and defense doctrine, the centerpiece of this contribution is the analysis of 75 official statements delivered during the Trump era (since January 2017 to January 2021), by Iran's high officials including the Supreme Leader and his Senior Advisors, Iran's President, 
members of parliament, IRGC officials, the Defense Ministry, the Ministry for Foreign Affairs, Imams of Friday Prayers, individual political, strategists and experts. Official speeches and narratives have been retrieved from official websites, as well as official national and international newspapers.

The paper is structured as follows. The next section presents Iran's military doctrine and the background of Iran's BMP followed by the narrative analysis on the BMP in Iran's strategic culture. The third section focuses on the narratives delivered from 2018 to 2019, including those related to the US withdrawal from the nuclear deal and the shooting down of US drone by IRGC in Persian Gulf. The last section demonstrates the change towards a more offensive approach in Iran's defense and foreign policy, while emphasizing the importance of the assassination of General Soleimani as a new turning point in this policy.

\section{IRAN'S MILITARY DOCTRINE AND ITS BALLISTIC MISSILE PROGRAM}

Iran's military doctrine is a fusion of western military concepts with ideological tenets, including martyrdom and revolutionary zeal (McInnis, 2017; Murray and Woods, 2014; Ward, 2005). Since the 1979 revolution, the Iranian military doctrine has evolved and adapted, reflecting the shift of the leadership's threat perceptions and regional political developments (Connell, 2010; Olson, 2016). Since the mid-1980s, Iran has adopted a defensive doctrine characterized by the development of ballistic missiles as a deterrence and defense mainly by irregular forces in asymmetric warfare. In this, Iran has drawn heavily on the lessons learned during its eight-year-long war with Iraq (Murray and Woods, 2014; Eisenstadt, 2015).

While Iran's first attempt to build ballistic missiles and high-level artillery goes back to the Pahlavi era in 1977, the approach to the program changed critically during and after the Iran-Iraq war (1980-1988), known as War of the Cities, when Iran's towns and cities were attacked by missiles, causing a high number of casualties (see table 1). All of Saddam missile strikes took place after Iraq defeats in ground and naval operations. This raised the idea that defending the borders by ground forces is not enough in the war with Iraq since Iraq was invading the depth of the country with long-range missiles. Therefore, the development of BMP with the assistance of Syria, Libya, China and North Korea became critical to Iran ${ }^{6}$. Given the fact that the War of the Cities was largely ignored by the international community, the missile program as part of Iran strategic culture has become intricately connected with the ideas of self-reliance and it is underpinned by distrust towards the West and the US (Taremi, 2014; McInnis, 2017). Since Iraq's attack was aimed at containing Iran's revolution, the 'revolutionary' state foundation has been closely related to the missile program (Adib-Moghaddam, 2006).

6. IRGC Official website, available at: www.Sepahnews.com. 
TABLE 1.

IRAQ Missile atTacks on Iran's DURING the War of the Cities

\begin{tabular}{lccc}
\hline Date & Attacked cities & Killed & Injured \\
\hline October 1983 & Dezful; Masjed-Soleiman (2) & 39 & 111 \\
\hline November 1983 & $\begin{array}{c}\text { Masjed-Soleiman; Behbahan; Khorramabad; } \\
\text { Andimeshk; Nahavand (5) }\end{array}$ & 96 & 214 \\
\hline February 1984 & $\begin{array}{c}\text { Dezful; Mahabad; Islam-Abad; Abadan; } \\
\text { Hamidieh; Ramhormoz (5) }\end{array}$ & 207 & 145 \\
\hline March-April 1985 & $\begin{array}{c}\text { Tehran; Shiraz; Isfahan; Tabriz; Ilam; } \\
\text { Hamedan; Zanjan; Kermanshah (8) }\end{array}$ & 898 & 3041 \\
\hline January-April 1987 & $\begin{array}{c}\text { Shiraz; Ahvaz; Tehran; Khorramabad; } \\
\text { Isfahan, Qom; Tabriz (7) }\end{array}$ & 469 & 4461 \\
\hline February 1988 & $\begin{array}{c}\text { Tehran; Shiraz; Qom; Karaj; Isfahan; } \\
\text { Tabriz; Orumieh; Borujerd (8) }\end{array}$ & $\mathbf{6 2 7}$ & 3900 \\
\hline Total & $\mathbf{2 3 ~ c i t i e s ~}$ & $\mathbf{2 3 3 6 \simeq ~} \mathbf{1 1 8 7 2 \simeq}$ \\
\hline
\end{tabular}

Source: Own elaboration.

Since 1984, Iran's leadership started a systematical investigation into its own missile technology. If after 2003 and the US attack on Iraq, a US invasion became Iran's main threat (Connell, 2010), the threat posed by Israel has always existed in Iran's defense doctrine (Eslami and Vieira, 2021). By 2005, Iran's defense doctrine has been referred to as a "mosaic defense", reflecting an asymmetrical approach by the IRGC and the Army (Artesh), through the mobilization of a large and dispersed militia force to engage in attritional warfare against the invading forces (Olson, 2016), in addition to naval and air-defense capabilities.

Since 2012, the emergence of terrorist groups in the region and insecurity at the borders also affected Iran's military doctrine. The "forward defense" doctrine implies that Iran should fight its enemies outside its borders to prevent insecurity of its soil. Five main aspects show Iran's new offensive approach: proxies, drone and naval warfare (speed boats), BMP and cyber technologies (Yossef, 2019). In addition to direct involvement by the IRGC forces in the war in Syria in support of Bashar Assad's regime since 2012, Iran has expanded its network of military allies beyond Hezbollah in Lebanon (Ahmadian and Mohseni, 2019).

More recently, Iran declared that IRGC "spent 17 billion dollars in the region" to support its allies, known as mostazafin and "neutralize 7 trillion investment of the US against the Muslim nations of the region" ${ }^{8}$. This network approach has involved

7. Naghdi, M. 2021. "Iran spent 17 billion dollars in the region in the past 30 years", Deutsche Welle. Available at: https://www.dw.com/fa-af/ (accessed: January $\left.3^{\text {rd }}, 2021\right)$.

8. Hajizadeh, A. 2021. "Iran neutralized the result of the 7 trillion investment of the US in the region”, Islamic Republic of Iran National Television, January 15 ${ }^{\text {th }}, 2021$. 
forming Shiite groups (from Lebanon, Syria, Iraq, Afghanistan and Pakistan) to fight alongside the IRGC in Syria, supporting Iraq's Mobilization Forces since 2014 in the fight against ISIS, and providing vital military support and advice to the Houthis in Yemen. While the support of Mustazafin is considered the "main responsibility of Quds IRGC", "missile power of Hezbollah and Gaza has been built by Iran's support" $"$.

Thus, Iran's BMP has crucial importance to its foreign and defense policy, something that is firmly rooted in Iran's strategic culture. This explains BMPs' connection to Iran's "national pride and the source of legitimacy" obtaining self-sufficiency at all levels (Eisenstadt, 2011) and the aspiration to demonstrate the accuracy of BMP. In particular, Ayatollah Khamenei's aspiration to produce very accurate missiles has been closely linked to the idea that the killing of non-military innocents is prohibited in Shia (Abdi and Hashemi, 2018). Hence Iran's tendency to publish images and videos of missile strikes, including attacks on ISIS positions and the US drone incident, or the choice of the title for the military exercise at the border of Turkey after the latter's invasion to Syria "One Target, One Shot" 12 proves the importance of weapon accuracy in Iran's strategic culture.

Finally, Iran's BMP and its role in Iran's strategic culture is intertwined with the identification of deterrence, first and foremost, against Israel as the major threat and enemy of Iran, as well against the Zionist lobby influencing international politics, in the so-called "global arrogance". Against this background, Iran's missile capability is a critical means of deterrence: being surrounded by US and Israel military bases makes it necessary for Tehran to improve its military capabilities such as a ballistic missile program to defend itself and make deterrence (Eisenstadt, 2011).

This issue has been essentially reinforced by the recent confrontation between Iran and the US in the region, including the assassination of General Qasem Soleimani and Professor Mohsen Fakhrizadeh; Iran's attack on Ain Al-Assad and Al-Taji military bases in Iraq by Iran; and US provocative military action through the presence of US aircraft-careers and B52 bombers in the Persian Gulf region. In this line, and along with its political propaganda, Iran has unveiled an advanced ballistic missile called "Haj Qasem" with a range of $1800 \mathrm{~km}$ and the so-called "Abu-Mahdi" naval cruise missile with a range of $1000 \mathrm{~km}$. Considering Iranian officials' statements on revenging the assassination of both Soleimani and Fakhrizadeh, celebrated as national

9. Hejazi, M. 2021. "We are responsible for the support of mustazafin", Deutsche Welle. Available at: https://www.dw.com/fa-af/ (accessed: January $3^{\text {rd }}, 2021$ ).

10. Hajizadeh, A. 2021. "Missile power of Hezbollah and Gaza is the result of Iran's support", Deutsche Welle. Available at: https://www.dw.com/fa-af/ (accessed: January 3 $3^{\text {rd }}, 2021$ ).

11. Ayatollah Khamenei, A. 2017. "Missiles are the source of legitimacy", Official website. Retrieves from http://farsi.khamenei.ir (accessed : October 21 $1^{\text {st }}$, 2017).

12. Bob, J. Y. 2019. "Iran launches Turkey border exercise after Erdogan invades Syria", Jerusalem-Post, October $11^{\text {th }}$ (available at: https://www.jpost.com/middle-east/iran-launches-turkey-border-exercise-after-erdogan-invades-syria-604167). 
heroes, further employment of BMP is expectable. A reflection of this was the statement by the General Staff of the Armed Forces Mohammad Hossein Bagheri following the agreement between the United Arab Emirates (UAE) and Israel stating "We consider UAE as the source of instability in the region and from now they will be our legitimate target"13.

According to the US Worldwide Threat Assessment issued in February 2016 (Izewicz, 2017), Iran has nowadays the "largest inventory of ballistic missiles in the Middle East" (see table 2). US negotiators hoped that the missile program would be subject to the round of negotiations following the conclusion of the JCPOA, but US withdrawal from JCPOA prevented any further developments. Iran's authorities have reiterated that its missile program is nonnegotiable (Bahgat, 2019).

TABLE 2 .

SOME OF THE IMPORTANT MISSILES OF IRAN

\begin{tabular}{lccccc}
\hline Name & $\begin{array}{c}\text { Range } \\
(\text { KM) }\end{array}$ & Type & $\begin{array}{c}\text { Weight (KG) } \\
\text { (Whole-Warhead) }\end{array}$ & $\begin{array}{c}\text { Length } \\
\text { (M) }\end{array}$ & Fuel \\
\hline Sejjil & 2000 & Ballistic-Surface to Surface & $23540-650$ & 17.90 & Solid \\
\hline Khorramshahr & 2000 & Ballistic-Surface to Surface & $26000-1800$ & 13 & Liquid \\
\hline Emad & 1700 & Ballistic-Surface to Surface & $17500-750$ & 15.5 & Liquid \\
\hline Ashura & 2500 & Ballistic-Surface to Surface & NA-750 & 23 & Solid \\
\hline Qiam & 800 & Ballistic-Surface to Surface & $6250-645$ & NA & Liquid \\
\hline Fateh 110 & 300 & Ballistic-Surface to Surface & $3670-500$ & 8.9 & Solid \\
\hline Ghadr-F & 2000 & Ballistic-Surface to Surface & $17458-640$ & 15.86 & Liquid \\
\hline Fateh 313 & 500 & Ballistic-Surface to Surface & $4500-N A$ & 8.86 & Solid \\
\hline Sumaar & 700 & Cruise & $1210-410$ & 6 & Solid \\
\hline Hormuz & 300 & Anti-Warship & NA-600 & NA & Solid \\
\hline Ya Ali & 700 & Air to Surface & $670-120$ & NA & Solid \\
\hline Persian Gulf & 300 & Ballistic-Surface to sea & $3730-450$ & 8.9 & Solid \\
\hline Hoveizeh & 1350 & Cruise & NA-NA & 6 & Solid \\
\hline Kowsar & 20 & Cruise & $100-30$ & 2.6 & Solid \\
\hline Qader & 1500 & Cruise & NA-200 & 7.4 & Liquid \\
\hline Zolfaghar & 700 & Ballistic-Surface to Surface & $4620-450$ & 10.3 & Solid \\
\hline Nasr & $35 \mathrm{k}$ & Anti-Warship & $350-150$ & 3.5 & Liquid \\
\hline Noor & 120 & Cruise & $715-175$ & 6.38 & Solid \\
\hline Ra'ad & 350 & Anti-Tank & $23-12$ & 0.98 & Solid \\
\hline & & & &
\end{tabular}

13. Bagheri, M. 2020. August 15). UAE will be our legitimized target. Deutsche Welle. Available at: https://www.dw.com/fa-af/ (accessed: August 15 ${ }^{\text {th }} 2020$.) 


\begin{tabular}{lccccc}
... ... & $\begin{array}{c}\text { Range } \\
\text { (KM) }\end{array}$ & Type & $\begin{array}{c}\text { Weight (KG) } \\
\text { (Whole-Warhead) }\end{array}$ & $\begin{array}{c}\text { Length } \\
\text { (M) }\end{array}$ & Fuel \\
\hline Bavar 373 & 320 & Surface to air & NA-NA & NA & NA \\
\hline Mersad (Shahin) & $45-80$ & Surface to air & NA-NA & NA & NA \\
\hline $\begin{array}{l}\text { Mersad } \\
\text { (Shalamche) }\end{array}$ & 40 & Surface to air & 637 & 5.03 & NA \\
\hline Shahab 1 & 300 & Scud-Surface to Surface & $5900-950$ & 11.25 & Solid \\
\hline Shahab 2 & 500 & Scud B-Surface to Surface & $5900-950$ & 11.25 & Solid \\
\hline Shahab 3 & 2000 & Ballistic-Surface to Surface & $15000-670$ & 15 & Liquid \\
\hline Fajr & 43 & Surface to Surface & $407-85$ & 5.2 & Liquid \\
\hline Dezful & 1000 & Ballistic-Surface to Surface & NA-450 & 12 & Solid \\
\hline Zelzal 3 & 210 & Ballistic-Surface to Surface & $3250-900$ & 3.5 & Solid \\
\hline Arash 4 & 40 & Ballistic-Surface to Surface & NA-NA & 2.89 & Liquid \\
\hline Sayyad 1-2 & 60 & Surface to Surface & $2320-200$ & 10.84 & Hybrid \\
\hline Zafar & 25 & Anti-Warship & $120-30$ & 2.68 & Solid \\
\hline Zoubin & 20 & Air to Surface & $560-340$ & 3 & Solid \\
\hline Haj Qasem & 1800 & Ballistic-Surface to Surface & $7000-500$ & 11 & Solid \\
\hline Abu Mahdi & 1000 & Cruise & NA-NA & NA & Solid \\
\hline Val-fajr & NA & Underwater torpedo & NA-250 & NA & Liquid \\
\hline Hoot & 360 & Underwater torpedo & $2700-210$ & 8.2 & Liquid \\
\hline Test-71 & 20 & Underwater torpedo & $1800-205$ & NA & Liquid \\
\hline & & & & & \\
\hline
\end{tabular}

Source: Own elaboration.

\section{NARRATIVE ANALYSIS OF IRAN'S BALLISTIC MISSILE PROGRAM}

Generally, Iran's strategic culture creates the room for maneuver for two narratives about Iran's BMP, corresponding to two main currents of thoughts to which Iran's elites adhere, namely the "revolutionary" and the "moderation" ones (AdibMoghaddam, 2012; Firuzabadi, 2014); each of them with its own specific approach to domestic and international issues (Eslami and Vieira, 2021) and its own interpretation of Iran's history, Shia identity and sense of threat and deterrence.

The "revolutionary" narrative on the BMP is rooted in Iran's revolutionary national identity (Adib-Moghaddam, 2012) and it links together the so-called "issue" and the "international system" narrative (Miskimmon et al., 2014). Thus, the BMP becomes a symbol of "superior counter-discourse" (Adib-Moghaddam, 2012: 278; Ramazani, 2004), while leaving no room for negotiation. This narrative has two important characteristics: firstly, it interprets the deterrent/strategic culture as a necessarily "offensive" / "essentialist" one; secondly, it is highly skeptical of the international 
cooperation and especially of the US (global arrogance); according to this narrative, the BMP has the highest strategic priority, something that demands unambiguous support on the part of Iran's institutions and society.

The "revolutionary narrative" combines a particular discourse of "deterrence" resonating with Iran's strategic culture, with the "offensive" discourse. The deterrence dimension, which is related to Iran's strategic culture, is reflected in several discourses. This is the case of the statement by Ahmad Alamal-Hoda, the Imam of Mashhad, conveying that " $[b] y$ having the missile, we do not need a nuclear bomb: a missile strike on the Dimona reactor is enough"14, or the claim that the US and its allies forces and their presence in the region can be mitigated because " $[\mathrm{w}] \mathrm{e}$ know how to confront them, with the launch of 500 ballistic missiles at the same time, we are able to destroy all of US forces in the region" 15 .

Another statement holds that "[w]e will defend our country when the attack begins, but the aggressive power and the ability of our strike after the start of the war will be devastating and regrettable for aggressors"16. The "revolutionary" narrative also affirms that "[w]e will not start any war, and the missiles are the means of defense" ${ }^{17}$. While the deterrent dimension of the "revolutionary narrative" strongly draws upon the strategic culture, there is an important offensive in it as well, reflected in the idea that "Israel will not exist in the next 25 years"18, implying Israel's auto-destruction or collapse.

Another reflection of the offensive dimension appears in the justification of the range of Iran's ballistic missiles. Accordingly, a self-restriction has been imposed on the range of missiles on the basis of the Shia religion. These limitations have been projected by Hajizadeh, who stated that "the reason we designed the 2000-kilometer missile, it's aimed at targeting our main enemy, the Zionist regime"19. Moreover, the 'revolutionary narrative' is resolutely against any kind of ideas related to restricting or destroying Iran's $\mathrm{BMP}$, as this is equivalent to the situation of "whenever the US wants, it can attack us" ${ }^{20}$. This particular discourse strongly draws upon the precedent of Libya. Therefore, the

14. Joffere, T. (2019, July 07). Tehran Imam threatens missile attack on Dimona. Jerusalem-post. Available at: https://m.jpost.com (accessed: July $7^{\text {th }} 2019$ ).

15. Hajizadeh, A. 2021. We know how to confront the US. Published in national television if Islamic Republic of Iran. (January $15^{\text {th }} 2021$ ).

16. Mousavi, A. (2019, July 14). Iran's offensive power will destroy the enemy. Mashregh. Available at: https://mashreghnews.ir/amp/974990/ (accessed: July 14 $4^{\text {th }} 2019$ ).

17. Velayaty. A. 2017. Iran will not start any war. Rokhdad. Available at: https://rokhdad.news/tag/ (accessed: December 21 $1^{\text {st }}$ 2017).

18. Ayatollah Khamenei, A. 2015. Israel will not exist in the next 25 years. Official-website. Retrieves from: http://english.khamenei.ir (accessed: September $9^{\text {st }} 2015$ ).

19. Hajizadeh, A. 2016. Iran has designed the missile with the range of $2000 \mathrm{Km}$ to target Israel. $B B C$.

20. Rahimpur, A. 2018. If we do not make missiles the US will attack us. Ana. Available at: https:// ana.ir (accessed: August $4^{\text {th }}$ 2018). 
narrative portrays a negotiation as "poison that kills" 21 , while it is also established that "the range limitation of $2000 \mathrm{~km}$ " of Iran's existing missiles "is not forever" 22

In addition, the "revolutionary narrative" is strongly skeptical of international cooperation. Accordingly, this narrative holds that missiles, not talks, are Iran's future. This narrative allows specific actors such as Ebrahim Raeesi to scale up the 'revolutionary' content and stablish red lines for Iran's foreign policy. Consequently, "negotiation with the killers of General Soleimani is haram (unlawful in Islam), we will meet American terrorists sooner or later for revenge and not negotiation" 23 .

The metanarrative of which this particular discourse is part of is the so-called "global arrogance". Here, the "revolutionary narrative" holds that "the only way for a country to guarantee peace and security" ${ }^{24}$ is to rely on its own forces and, in case of Iran, on the BMP. This makes Iran's BMP non-negotiable, what conveys a strong conviction in Iran's deterrence, a domestically oriented narrative with the message that: "neither a war will happen; nor will we negotiate" 25.

Finally, the "revolutionary narrative" attributes a sense of progress and a positive meaning to the missile program as such, thereby reinforcing the central role of missiles in Iran's strategic culture. This is reflected, for instance, in statements with references to the Palestine military action in Iran's official discourse, such as "Palestinians use missiles instead of rocks" as "progress" 26 .

As for the "moderation" narrative, it also resonates with Iran's strategic culture, maintaining that the BMP is non-negotiable and key to Iran's deterrence. Iran's missile program is therefore seen as "one of the most long-lasting policies of the Islamic Republic"27. At the same time, the narrative holds that cooperation is possible and problems can be solved through dialogue and negotiation. This narrative attributes high importance to economic power and the balance between the economic and military dimensions of Iran's foreign policy.

An illustration of this "moderation narrative" is its critical positioning towards the ballistic missile tests conducted by IRGC since 2015, after the nuclear deal was signed.

21. Ayatollah Khamenei, A. 2019. Negotiation is poison. Official-website. Available at: http://farsi. khamenei.ir (accessed: May 14 $\left.{ }^{\text {th }} 2019\right)$.

22. Hajizadeh, A. (2021, January 03). Range limitations of Iran's missiles is not forever. Deutsche Welle. Available at: https://www.dw.com/fa-af/ (accessed: January $4^{\text {th }} 2021$ ).

23. Raeesi, E. 2020. Negotiation with the killers of General Soleimani is Haram. Tansim. Available at: https://www.tasnimnews.com/fa (accessed: January $27^{\text {th }} 2020$ ).

24. Rahimpur, A. 2018. If Global arrogance finds Iran weak will attach quickly. Mashregh. Available at: https://www.mashreghnews.ir (accessed: September 29 $9^{\text {th }} 2018$ ).

25. Ayatollah Khamenei, A. 2019. Neither a war will happen; nor will we negotiate. Official-website. Available at: http://english.khamenei.ir (accessed: May 14 $\left.{ }^{\text {th }} 2019\right)$ ).

26. Ayatollah Khamenei, A. 2019. Rockets instead of rocks. Radio-Farda. Available at: https:// www.google.pt/amp/s/www.radiofarda.com/amp/30068932.html (accessed: May 14 ${ }^{\text {th }}$ 2019).

27. Nobakht, M. 2017. Missiles are one of the most long-lasting policies of Iran. Azer. Available at: http://azenglishnews.com/guney (accessed: May 17 ${ }^{\text {th }}$ 2017). 
While having missiles for defense and deterrence has been considered important, IRGC had to act with caution while insisting that "everything has its own time", contrary to the "revolutionary narrative" that holds that there can be no time limitation for developing the most important strategic program of a country; it is rather "now or never". After the ballistic missile test by IRGC in 2015, the revolutionary narrative has become stronger, conveyed by different political actors, such as Motahari who noticed that "while it is always maintained that conservatism is always bad and it is better to be moderated" 28 or Lahouti, for whom "the development will not be achieved by making a wall around the country" 29 .

The "moderation narrative" is especially concerned with the fact that an excessive emphasis on dissuasion would provoke international actors to impose even more stringent economic sanctions, which would eventually increase tensions, thereby pushing Iran to a more belligerent posture, in which Iran's friends are rare. In Motahari's words, "only two friend countries remained for us, Syria and Venezuela" ${ }^{30}$. At the same time, adherence to the 'revolutionary narrative' gives a carte blanche to the non-implementation of JCPOA ${ }^{31}$. Accordingly, actors who are engaged in provocative actions (including tested missiles immediately after JCPOA), "effectively preventing the implementation of the nuclear deal" 32 bear the consequences of Iran's unstable economy and new sanctions.

\section{The US withdrawal from JCPOA and the Drone incident (2018-2019)}

The US withdrawal from the nuclear deal has influenced Iran's defense program and, most importantly, its BMP. Trump always criticized Obama for making that "Bad Deal" and paying 150 billion dollars to Iran to develop its ballistic missile program and increase its domination over the region ${ }^{33}$. This led to US withdrawal from Iran's nuclear deal with the aim of making a new "Better Deal" which would

28. Motahari, A. 2018. Missile test after JCPOA and did not let the nuclear deal to be implicated. Radio-Farda. Available at: https://www.radiofarda.com/a/alimotahari-rocket-therevolutionaryguards-/29401360.html (accessed: July 29 ${ }^{\text {th }} 2018$ ).

29. Lahouti, M. 2019. We cannot make a wall around the country. Irna. Available at: https://www. irna.ir/news/ (accessed: January $22^{\text {nd }} 2019$ ).

30. Motahari, A. 2021. Iran has only two friends. Mashregh. Available at: https://mashreghnews.ir/ amp/ (accessed: January $1^{\text {st }} 2021$ ).

31. Motahari, A. 2018. Missile test after JCPOA was wrong. Jahan. Available at: http://www. jahannews.com accessed: August $10^{\text {th }} 2018$ ).

32. Motahari, A. 2018. Missile test after JCPOA and did not let the nuclear deal to be implicated. Radio-Farda. Available at: https://www.radiofarda.com/a/alimotahari-rocket-therevolutionaryguards-/29401360.html (accessed: July 29 ${ }^{\text {th }} 2018$ ).

33. Trump, Donald. 2018. "President Donald J. Trump Is Ending United States Participation in an Unacceptable Iran Deal” White House, May 8th. Available at: https://trumpwhitehouse. 
include Iran's BMP, too (Kroenig, 2018) ${ }^{34}$. This deal would not only prevent Iran from achieving a nuclear bomb, but it would also limit Iran's BMP, so to preserve the security for Israel and US national interests in the region (id.).

The US withdrawal from the nuclear deal increased a sense of mistrust in Iran. That is why even if the "revolutionary narrative" grew already stronger before April 2018, US withdrawal from the JCPOA made the "moderation" narrative disappear almost completely. The skepticism about international cooperation that emerged in Iran after that event is properly projected in Ayatollah Khamenei's statement when he affirmed that "the evil US once again showed that trust to Great Satan is wrong"35. In line with this, Mohsen Rezaee, the former head of IRGC stated that "once the US tested our will and we gave them a slap with 19000 centrifuges, this time also we will come back with thousandths of centrifuges and millions of missile; however there will not be any negotiation in the future" 36 and the US has to apologize to Iranian nation and come back to the negotiation table ${ }^{37}$.

The drone incident produced a new extreme variation of the "revolutionary" narrative informed by strategic culture, making that narrative the dominant one. The dominant post-2018 narrative clearly resonates with Iran's strategic culture. Thus, "[o] ur military forces took a clever step and acted on their legal duty, our military forces are ready to defend. Missiles can be deterrence power" ${ }^{38}$. The narrative echoes in Iran's official discourse, according to which it has been stated that "[o]ur borders are our red line and nobody is allowed to joke with us about our red line ${ }^{39}$. In addition, this narrative establishes a strong connection between the current affairs and Iran's past, which is reflected in the recurrent statement that "hit and run is over" 40 . The narrative, therefore, holds that if a country hits us, we will hit back; if they attack, we will attack back; and if they seize, we will seize back. This creates an additional

archives.gov/briefings-statements/president-donald-j-trump-ending-united-states-participation-unacceptable-iran-deal/.

34. See also: Trump, Donald. 2018. "President Donald J. Trump Is Ending United States Participation in an Unacceptable Iran Deal" White House, May 8th. Available at: https:// trumpwhitehouse.archives.gov/briefings-statements/president-donald-j-trump-ending-united-states-participation-unacceptable-iran-deal/.

35. Ayatollah Khamenei, A. 2018. The evil US once again showed that trust to the Great Satan Official-website. Available at: http://farsi.khamenei.ir (accessed: December $9^{\text {th }}$ 2018).

36. Rezaee, M. 2019. The US should not have tested our will again. Tasnim. Available at: https:// www.tasnimnews.com/fa (accessed: February $8^{\text {th }} 2019$ ).

37. Rouhani, H. 2019. The US has to apologize Iranian nation and come back to JCPOA. $B B C$.

38. Motahari, A. 2019. Missile can be the deterrence power. Tabnak. Available at: https://www. tabnak.ir/fa/news/906965/ (accessed: June 21 $1^{\text {st }} 2019$ ).

39. Hajizadeh, A. 2019. Nobody is allowed to joke with us about our red lines. Khabar-Online. Available at: https://www.khabaronline.ir/amp/1272506/ (accessed: June 22 ${ }^{\text {nd }} 2019$ ).

40. Ayatollah Khamenei, A. 2015. Hit and run is over. Official-website. Available at: http://english. khamenei.ir (accessed: May $\left.6^{\text {th }} 2015\right)$. 
reinforcement for the position on the missiles as well, allowing the Iranian leader to state: "If something happens, we will not ignore it as before; our response to a missile will be a missile" 41 .

Moreover, the dominant post-2018 narrative acquires more and more "revolutionary" characteristics. Accordingly, Iran's BMP is celebrated as a symbol of Iran's national identity. President Rouhani demonstrates his appreciation by stating that is ready to "kiss the hand of the defense ministry for making the system and also I kiss the hand of IRGC forces for their effort to defend Iran's border"42.

Still, the dominant narrative increasingly expels the "moderation" one from the narrative space. As such, it helps to convey the idea that "[i]f the US attacks my country, I will not be a political theoretician. I am a fighter who takes weapons to defend the country" ${ }^{\prime 3}$. The discourses of moderation remotely imply that the shooting down of a drone had diplomatic alternatives, are coached in very careful terms and marginal(ized), thus stating that "[o]ne of the dimensions of the legitimacy of Islamic system is defense power and the other one is Diplomacy" 44 .

Thus, there is a tendency towards the "revolutionary" narrative, reinforcing the effect of direct sanctions imposed on Ayatollah Khamenei and Javad Zarif, respectively in June and August 2019, thereby closing all negotiation doors; something that conveys the idea that " $[\mathrm{t}]$ he time of this discourse is over" ${ }^{\text {" }}$. In the statements related to this step, Iran's leadership has equated the Iran Air 655 incident to the US constantly belligerent and aggressive policy. In their view,

imposing sanctions on Iran's Leader and foreign minister means that the US does not want to negotiate. [...] The US, which is so proud of bellicosity, since Vietnam which war it has won so far? Whenever they entered the Persian Gulf, they committed atrocities. The worst of which was the killing of 290 innocent people in an attack on the Islamic Republic Airbus (655) Airlines. [...] UK has blocked our tanker collaborating with the US economic terrorism [...] IRI is responsible for the security of Persian Gulf and as the British tanker was breaking international maritime law, we have blocked it ${ }^{46}$.

41. Rezaee, M. 2019. Our response to the missile will be a missile. Alef. Available at: https://www. google.pt/amp/s/www.alef.ir/news/3980510006.html\%3fshow=amp (accessed: August 2nd 2019).

42. Rouhani, H. 2019. "I kiss the hands off IRGC for making missile power", Irna. Available at: https://www.irna.ir/news/ (accessed: June 25th, 2019).

43. Ziba-kalam, S. 2019. I am a fighter who takes weapons to defend the country. Entekhab. Available at: https://www.entekhab.ir/fa/news/483414/ (accessed: June 17 ${ }^{\text {th }} 2019$ ).

44. Kavakebian, M. 2019. One of the dimensions of the legitimacy of Islamic system is defense power. Icana. Available at: https://www.icana.ir/Fa/Newsamp/429522/ (accessed: June $17^{\text {th }} 2019$ ).

45. Zarif, J. 2019. The US has to stop selling weapons to new Saddams. Official-website. Available at: https://www.mfa.ir/portal/newsview/41789/ (accessed: June 30 $0^{\text {th }} 2019$ ).

46. Id. 
TABLE 3 .

NARRATIVE ANALYSIS OF IRANIAN POLITICAL NARRATORS BEFORE AND AFTER THE DRONE INCIDENT

\begin{tabular}{|c|c|c|}
\hline Narratives & Moderation & Revolutionary \\
\hline \multirow{4}{*}{$\begin{array}{l}\text { Before } \\
\text { drone } \\
\text { incident }\end{array}$} & Economy is as important as BMP & BMP is legitimized deterrence \\
\hline & IRI will never use its missiles & Hit and run is over \\
\hline & BMP is the most long-lasting policies & Israel has to be destroyed \\
\hline & BMP prevented implication of JCPOA & A new superpower is born \\
\hline \multirow{5}{*}{$\begin{array}{l}\text { After } \\
\text { drone } \\
\text { incident }\end{array}$} & $\begin{array}{l}\text { BMP is national pride and } \\
\text { international prestige }\end{array}$ & Global arrogance fears to attack IRI \\
\hline & The BMP is unnegotiable & $\begin{array}{l}\text { IRI's response to missile attack is a } \\
\text { missile attack }\end{array}$ \\
\hline & $\mathrm{BMP}$ is legitimized deterrence & $\begin{array}{l}2000 \mathrm{KM} \text { range is enough to destroy } \\
\text { Israel }\end{array}$ \\
\hline & $\begin{array}{l}\text { We are kissing IRGC's hand for } \\
\text { producing the missiles }\end{array}$ & $\begin{array}{l}\text { An attack to Dimona reactor would be } \\
\text { enough }\end{array}$ \\
\hline & $\begin{array}{l}\text { BMP is national pride and } \\
\text { international prestige }\end{array}$ & IRI's BMP is not only defense \\
\hline
\end{tabular}

Source: Own elaboration.

Shifting toward a more offensive approach (2020-2021)

The assassination of General Soleimani is considered as an important turning point on Iran's BMP and opened a new chapter in Iran's defense policy. On January 3rd, 2020, General Qasem Soleimani, the chief of Quds IRGC, was assassinated by airstrikes ordered by President Trump on Baghdad international airport. In retaliation, Iran attacked two US military bases in Iraq —Ain Al-Asad and Al-Taji-, which led to their destruction, the loss of warfare and the death of a number of troops portrayed by Iran's media as "an attack on the US hegemony" ${ }^{47}$. Iran's attack represented the first official attack on US military interests since the end of the Second World War.

With the assassination of General Soleimani, the revolutionary narrative surrounding Iran's strategic culture reached its peak. Almost all Iranian officials condemned this act and asked for a 'decisive revenge'. This was reflected in Ayatollah Khamenei's statement that the "attack on Ain Al-Asad was only a slap given to

47. Ebadi, M. (2021, January 07). Attack on Ain Al-Assad was an attack on the US hegemony. Borna. Available at: http://www.bornanews.ir (accessed: January $7^{\text {th }}$ 2021). Anonymous. (2020, January 08). Hunting the paper tiger of the US (the first attack on the US after the Second World War. Tasnim News. Available at: https://www.tasnimnews.com/fa. (accessed: January $8^{\text {th }}$ 202). 
Americans" ${ }^{38}$, implying that the retaliation itself was an ongoing process. President Rouhani also condemned the assassination and stated that "the US will not achieve its nefarious goals in the region, and Iran will retort this crime" 49 . Moreover, President Rouhani's Advisor Ashena threatened the US and stated that "any US strategic mistake will face a massive response which will turn to a full-scale war"50. Against this background, any traces of the "moderation" narrative were criticized, even in retrospective. Thus, for example, Hassan Rouhani, Javad Zarif and their administration were criticized for the negotiation with the US and compromising on Iran's nuclear power, under the rationale that accepting the restrictions on the nuclear program made Iran weaker and now the enemies dare to attack it. That is why it was proposed that "Rouhani and Zarif as well as Larijani must be taken to the court for betraying the country" 51 . In addition, the president has been criticized for tying the destiny of the country to the US elections, something that has been considered as an unacceptable act by Iran's elites. This was viewed as threatening the independency and self-sufficiency of the country. In this connection, President Rouhani claimed that "we are not excited for Biden's winning but we are so happy for the failure of Trump in the election" 52 .

Joe Biden's victory at the US 2020 presidential election has raised expectations in Iran, while it has also changed its policy towards its BMP. One of Biden's most important electoral promises was to go back to JCPOA. Therefore, his green light for negotiating with Iran and lifting the sanctions imposed by Trump came to center of attention in Tehran. Consequently, the economic pressures due to the sanctions especially after the mid-2020, and the hope for the possibility of cooperating with the new Democrat Government in the US, made the moderation narrative feasible again; as it was reflected in Mostafa Tajzadeh's statement claiming that "missile is good but peoples' livelihoods are more important, so Iran needs to negotiate with the US again" ${ }^{33}$. Similarly, President Rouhani stated that: "the doors of the negotiation are always open"54. However, some officials from the Biden administration put forward some preconditions for returning to JCPOA, including negotiation on Iran's BMP.

48. Ayatollah Khamenei, A. (2020, January 04). Attack on Ain Al-Asad was only a slap given to Americans Official-website. Available at: http://english.khamenei.ir (accessed: January $4^{\text {th }} 2020$ ).

49. Rouhani, H. (2020, January 08). The US will not achieve its nefarious goals. Irna. Available at: https://www.irna.ir/news/ (accessed: January $8^{\text {th }} 2020$ ).

50. Ashena, H. (2020, September, 16). Any US strategic mistake will face a massive response. Tansim. Available at: https://www.tasnimnews.com/fa (accessed: September $16^{\text {th }} 2020$ ).

51. Abbasi, H. (2020, March 23). Rouhani and Zarif as well as Larijani must be taken to court Available at: https://film.tebyan.net/film/319941/ (accessed: March $23^{\text {rd }} 2020$ ).

52. Rouhani, H. (2020, December 16). We are not excited for Biden's winning but we are so happy for the failure of Trump. Isna. Available at: https://www.isna.ir/news/ (accessed: December 16 ${ }^{\text {th }}$ 2020).

53. Tajzadeh, M. 2020 missile is good but peoples' livelihoods are more important. Mashregh. Available at: https://www.mashreghnews.ir/news (accessed: June 16th 2020).

54. Rouhani, H. 2021. The door for negotiation is Always open. $B B C$. 
This prompted Iran's foreign minister to state that "Iran will never negotiate on JCPOA again" 55 , as a result of what the project of a nuclear deal has been closed forever.

The assassination of Professor Mohsen Fakhrizadeh — the mastermind of Iran's nuclear and missile industries on November $27^{\text {th }} 2020$ raised the idea among Iranian elites that both killings were the "result of negotiation with the US"56. In this vein, "putting concrete in the heart of the Arak reactor is the reason why the US dares to kill our heroes" ${ }^{\prime 5}$. Eventually, the nuclear deal and accepting a compromise with the US were viewed as decreasing Iran's deterrence power. After the assassination of Fakhrizadeh, the importance of pursuing Iran's nuclear program has been reflected in the statements of several officials stating that "the enemy cannot stop our nuclear program with the terror of our scientists" 58 .

The assassination of these two Iranian representatives changed the orientations of Iran's missile policy. Soleimani's assassination consolidated the retaliatory aspect of Iran's missile program. Although retaliation as a fundamental principle has always existed in Iran's military policy, such an emphasis on it, especially in connection with the BMP, was rare. The necessity of retaliation has been reflected in the Supreme Leader's statement that "attack on Ain Al-Assad was not our revenge they [US] have to always be waiting for it" 59 and "I promise to take the revenge of General Soleimani" ${ }^{60}$. This also conveys the message that "Iran will have a decisive and destructive response for any strategic mistake of the enemy" ${ }^{\prime \prime}$. The issue of retaliation has come to the center of attention with the assassination of Fakhrizadeh. In this vein, "those who committed this heinous act must know that a hard revenge awaits them" 62 and "We will descend like lightning on the murderers of the Dr. Fakhrizadeh and we will regret them"63.

55. Zarif, J. 2020. JCPOA is a closed project. Euro-news. Available at: https://www.euronews. $\mathrm{com} / \mathrm{fa} /$ (accessed: December $3^{\text {rd }} 2020$ ).

56. Naghdi, M. 2020. The terror of Soleimani is the result of negotiation with the US. Isna. Available at: https://www.isna.ir/news/ (accessed: January $27^{\text {th }} 2020$ ).

57. Raefi-pour, A. 2021. JCPOA and closing Arak reactor led to Soleimani's assassination. Aparat. Available at: https://www.aparat.com/ (accessed: January $11^{\text {th }} 2021$ ).

58. Amouei, A. 2020. The enemy cannot stop our nuclear program with the terror of our scientists. Mashregh news. Available at: https://mashreghnews.ir/amp/ (accessed: November 28 ${ }^{\text {th }} 2020$ ).

59. Ayatollah Khamenei, A. 2020. Attack on Ain Al-Assad was not our revenge. Official-website. Available at: http://english.khamenei.ir (accessed: January $5^{\text {th }} 2020$ )

60. Ghaani, E. (2021, January 03). I promise to take the revenge of General Soleimani. BBC.

61. Salami, H. (2021, January 03). Iran will give a firm and decisive response to the enemy. Tabnak. Available at: https://www.tabnak.ir/fa/news (accessed: January 3rd 2021).

62. Bagheri, M. 2020. The proprietors of this heinous act must know that a hard revenge awaits them. Deutsche Welle. Available at: https://www.dw.com/fa-af/ (accessed: November $28^{\text {th }} 2020$ ).

63. Dehghan, H. 2020.We will descend like lightning on the murderers of Fakhrizadeh. Tansim. Available at: https://www.tasnimnews.com/fa. (accessed: November $28^{\text {th }} 2020$ ). 
The assassination of Fakhrizadeh had a serious influence on Iran's international cooperation, too. In late 2020, the Iranian Parliament approved two provocative laws related to the country's security policy. The first one obliges Iran's government to take some nuclear steps including the enrichment of 20 percent and adding 1000 new centrifuges to the circle of enrichment. Moreover, this law forces the government to withdraw from the JCPOA and the Nonproliferation Treaty (NPT) and "fire the inspectors of IAEA if other parties of the agreement do not perform their duties" ${ }^{\text {. }}$. This issue was faced with Zarifs reaction, who stated that "we are against the plan of the Parliament to withdraw from the JCPOA and NPT, but we have to implement it" ${ }^{\prime \prime}$. As for the second law, it committed the Government and Armed Forces "to make a comprehensive plan to destroy Israel by the end of 2040"66.

Offensive strategic actions after the assassination of Fakhrizadeh were not limited to the parliament and government. The judiciary power "put a red alarm in Interpol for Donald Trump" ${ }^{67}$ and forty seven other actors who were responsible for the assassination of Soleimani and Fakhrizadeh. The Iranian Army held its biggest drone exercise in its history. Accordingly, the Deputy Commander of the army claimed that "Iran is a Drone superpower" 68 . In addition, the IRGC released a new underground missile city in the South of Iran, which is related to IRGC Navy forces. In this regard, the Head of IRGC stated that "this is only one of the several underground missile bases, and we are ready to nip any possible threat in bud" ${ }^{69}$. Moreover, during a military exercise only a few days before Joe Biden's inauguration as US President, Iran launched a long-range missile to a warship replica in the Indian Ocean, while the target was "only 100 miles away from the US warships (USS Nimitz) and 20 miles away from a trade ship"70. This implies that, regardless of the possibility for international cooperation or further negotiations with the world's powers, the BMP remains the main defense strategy. Therefore, there is no possibility for the negotiation on Iran's missile program, what has deterred all possible attacks on the country

64. Ghalibaf, M. 2020 Iran will quit NPT. Deutsche Welle. Available at: https://www.dw.com/ fa-af/ (accessed: December $2^{\text {nd }} 2020$ ).

65. Zarif, J. 2020. We are against the plan of parliament to withdraw from the JCPOA and NPT. Euro-news. Available at: https://www.euronews.com/fa/ (accessed: December $3^{\text {rd }} 2020$ ).

66. Maleki, V. 2021. A plan to destroy Israel by the end of 2040. Mehr. Available at: https://www. mehrnews.com/ (accessed: January $1^{\text {st }} 2021$ ).

67. Esmaeeli, G. 2021. Iran put a red alarm for Donald Trump. Euro-news. Available at: https:// www.euronews.com/fa/ (accessed: January $4^{\text {th }} 2021$ ).

68. Dadras, M. 2021. Iran is a Drone superpower. Mehr. Available at: https://www.mehrnews. com/ (accessed: January $8^{\text {th }} 2021$ ).

69. Salami, H. 2021. We are ready to nip any possible threat in bud. Tabnak. Available at: https:// www.tabnak.ir/fa/news (accessed: January $3^{\text {rd }} 2021$ ).

70. Tomlinson,L. 2021. Iranian missiles land within 20 miles of ship, 100 miles from the Nimitz strike group in Indian Ocean. Fox News. Available at: https://www.foxnews.com/world/iranian-missiles-100-miles-nimitz-strike-group-indian-ocean (accessed: January 16 ${ }^{\text {th }} 2021$ ). 
TABLE 4.

IRAN'S SHIFTING NARRATIVES (2O2O- EARLY 2O2I)

\begin{tabular}{|c|c|c|}
\hline Turning Points & Revolutionary Narrative & Moderation Narrative \\
\hline \multirow{4}{*}{$\begin{array}{l}\text { Soleimani's } \\
\text { Assassination }\end{array}$} & $\begin{array}{l}\text { A slap was given to the US (attack } \\
\text { on Ain Al-Asad) }\end{array}$ & $\begin{array}{l}\text { The US will not achieve its nefarious } \\
\text { goals }\end{array}$ \\
\hline & An attack on the US hegemony & $\begin{array}{l}\text { Negotiation with the killers of } \\
\text { Soleimani is meaningless }\end{array}$ \\
\hline & $\begin{array}{l}\text { We will meet the US for revenge } \\
\text { and not negotiation }\end{array}$ & $\begin{array}{l}\text { Development of BMP is strongly } \\
\text { continuing }\end{array}$ \\
\hline & Israel has to be destroyed & $\begin{array}{l}\text { Iran will take the revenge of its } \\
\text { heroes }\end{array}$ \\
\hline \multirow{4}{*}{$\begin{array}{l}\text { The US 2020s } \\
\text { election }\end{array}$} & $\mathrm{UAE}$ is our legitimized target & $\begin{array}{l}\text { We cannot make a wall around the } \\
\text { country }\end{array}$ \\
\hline & The main revenge is still in process & $\begin{array}{l}\text { The US must come back to } \\
\text { diplomacy }\end{array}$ \\
\hline & $\begin{array}{l}\text { Negotiation with the killers of } \\
\text { Soleimani is forbidden }\end{array}$ & $\begin{array}{l}\text { The doors for the negotiation are } \\
\text { always open }\end{array}$ \\
\hline & $\begin{array}{l}\text { The negotiation is forbidden } \\
\text { (red-line) }\end{array}$ & $\begin{array}{l}\text { If the US apologize and repents we } \\
\text { will accept }\end{array}$ \\
\hline \multirow{5}{*}{$\begin{array}{l}\text { Fakhrizadeh's } \\
\text { Assassination }\end{array}$} & Iran will destroy Israel by 2040 & $\begin{array}{l}\text { Nuclear program won't stop with } \\
\text { terror of scientists }\end{array}$ \\
\hline & $\begin{array}{l}\text { We will descend like lightning on } \\
\text { the enemies }\end{array}$ & $\begin{array}{l}\text { We will retaliate in an appropriate } \\
\text { time }\end{array}$ \\
\hline & $\begin{array}{l}\text { Iran will kick the IAEAs inspectors } \\
\text { out of the country }\end{array}$ & $\begin{array}{l}\text { Iran will keep cooperating with the } \\
\text { IAEA }\end{array}$ \\
\hline & Who dares to negotiate about BMP? & $\begin{array}{l}\text { Iran defeats the US in diplomacy } \\
\text { once again }\end{array}$ \\
\hline & $\begin{array}{l}\text { Rouhani and Zarif must be taken to } \\
\text { the court for JCPOA }\end{array}$ & $\begin{array}{l}\text { We are against withdrawal from } \\
\text { NPT and JCPOA }\end{array}$ \\
\hline
\end{tabular}

Source: Own elaboration.

after the Iran-Iraq war. In this regard, while showing the capability of Iran's BMP for the destruction of US warships, the IRGC's officials conveyed the message that "destroying aircraft-carriers and warships using long-range BMP is one of Iran's defense strategies" 71 .

While Iran's strategic culture has always followed deterrence and self-sufficiency as two main principles, the assassination of Soleimani and Fakhrizadeh as the flag-bearers

71. Salami, H. 2021. Destroying aircraft-carriers and warships using long-range BMP is one of Iran's defense strategies. donya-e-eqtesad. Available at: https://donya-e-eqtesad.com/ (accessed: January $\left.18^{\text {th }} 2021\right)$. 
of Iran's deterrence and self-sufficiency is considered as a great loss for Iran. This consolidates the offensive dimensions of Iran's BMP and puts an absolute prohibition on any kind of negotiations with the US. This way, Iran "will never participate in a negotiation which limits its security and defense capabilities"72 and "we are not waiting for the US to be back to JCPOA, but we are in a hurry to lift the sanctions" "73. The prohibition of negotiation with the US has even been reflected in the narratives used by the officials who are known as moderated actors. In this way, "negotiation with the murderers of Soleimani is meaningless" 74 and "negotiation with the killers of Soleimani is forbidden" 75 .

The domination of revolutionary narratives in Iran's strategic culture - which emphasizes the prohibition of negotiation, the development of nuclear program, the expansion of ballistic missiles and the planning for the destruction of Israel- reached its peak in the last days of the Trump administration. In this vein, the Secretary of State Mike Pompeo claimed that all sensitive positions of Iran are occupied by hardliners and "you will have a better chance to find a unicorn in Iran" than a moderated actor $^{76}$.

\section{CONCLUSIONS}

The question guiding the present investigation was how does strategic culture contribute to our understanding of Iran's foreign and security policy towards the US under the Trump administration?

In this contribution, it has been argued that Iran's strategic culture has shaped Iran's foreign and defense policy, thereby "unpacking" the black box of Iran's foreign policy. This way, I have demonstrated that Iran's strategic culture is rooted in a particular historical political and geopolitical context which is shaped by two major principle: On the one hand, Iran's policy towards BMP is intertwined with the historical precedent of vulnerability, during a eight years period (1980-1988) when Iran was attacked by missiles. Being surrounded by US military bases and perceiving a serious, constant and imminent threat from Israel and the US, the feeling of vulnerability that informs Iran's strategic culture nowadays is additionally reinforced by the fact that Iran has antiquated

72. Raeesi, E. 2021. We will never participate in a negotiation which limits its security and defense capabilities. $B B C$.

73. Ayatollah Khamenei, A. 2021. We are not waiting for the US to be back to JCPOA. Offcial-website. Available at: .http://english.khamenei.ir (accessed: January $8^{\text {th }} 2021$ ).

74. Motahari, A. 2020. "Negotiation with the murderers of Soleimani is meaningless", Isna. Available at: https://www.isna.ir/news (accessed: June $6^{\text {th }}, 2020$ ).

75. Mousavi, A. 2020. Negotiation with the killers of Soleimani is forbidden. Sobheno. Available at: https://www.sobhenonews.com/ (accessed: June $8^{\text {th }} 2020$ ).

76. Pompeo, M. 2021. "You will have a better chance to find a unicorn in Iran than a moderated actor". Twitter. 
air forces which IRI cannot modernize due to extensive sanctions which prevents the country from buying aircrafts. Consequently, Iranian leadership's main concern is inevitably directed to create a powerful defense system, capable of defending its territory and deterring a "New Saddam Hussein" from an attack on Iran. On the other hand, US interference $S$ in Middle East countries and the occupation of Palestine territory by Israel are viewed as expressions of "global arrogance", which the Islamic Republic of Iran needs to confront by any diplomatic or, if necessary, military tools.

The present article has also demonstrated a change in narratives on the BMP in Iran. While Iran's defensive strategic culture has been traditionally supported by a mixture of both "revolutionary" "(Israel must be destroyed)" and "moderation" (Missile power not for use)' narratives, the present analysis suggests that a narrative shift is taking place since the US withdrawal from JCPOA. This shift towards a more offensive approach consolidated with the downing of the US drone and has reached to its peak due to assassination of General Soleimani. This murder also turned retaliation into a new principle in Iran's strategic culture and military doctrine.

Prior to 2017, a strong narrative had been promoted by Iranian moderated actors conveying criticism of the BMP. This narrative maintained that, although defense, security and deterrence had been very important, economic issues had to be taken more seriously. Based on this 'moderation' narrative, international cooperation oriented towards the resolution of Iran's economic problems was Iran's main priority, therefore outweighing other issues and portraying negotiation as the best method for Iran's international engagement and cooperation. On the other hand, the "revolutionary" narrative has viewed any systematic international cooperation with the West as a big strategic mistake that would inevitably lead to the destruction of the country. According to the "revolutionary" narrative, a strong defense power is the utmost priority of a country that is fighting for its survival.

Based on the present analysis, the "revolutionary" narrative after the drone incident, seizing British tankers and assassination of General Soleimani has grown stronger and supported by more actors. The shift towards revolutionary narratives was significant to the extent that even critical events such as the incident with the Ukrainian flight that caused 176 casualties could not revive the "moderation" narrative. It can be concluded that Iran's nowadays strategic culture has become offensive and supported by the "revolutionary" offensive narrative. This is reflected in IRGC statements and Iran's military doctrine. This claim can be proven by IRGC officials announcing that Iran's military doctrine has changed from a defensive approach to a defensive-offensive one.

\section{References}

Abdi, Hossein and Mohammad Hashemi. 2018. "Analyzing the concept of weapons of mass destruction and their adaptation to the Islamic point of view, with emphasis on the views of the Supreme Leader of Imam Khamenei”, Political Quarterly, 48 (3): 709-732. Available at: https://dx.doi.org/10.22059/jpq.2018.207307.1006804. 
Adib-Moghaddam, Arshin. 2005. "Islamic utopian romanticism and the foreign policy culture of Iran", Critique: Critical Middle Eastern Studies, 14 (3): 265-292. Available at: https://doi.org/10.1080/10669920500280623.

Adib-Moghaddam, Arshin. 2006. The international politics of the Persian Gulf: a cultural genealogy. London and New York: Routledge. Available at: https://doi. org/10.4324/9780203965320.

Adib-Moghaddam, Arshin. 2012. "What is Radicalism? Power and Resistance in Iran”, Middle East Critique, 21 (3): 271-290. Available at: https://doi.org/10.108 $0 / 19436149.2012 .717800$.

Ahmadian, Hassan and Payam Mohseni. 2019. "Iran's Syria strategy: the evolution of deterrence", International Affairs, 95 (2): 341-364. Available at: https://doi. org/10.1093/ia/iiy271.

Bahgat, Gawdat. 2019. "Iran's Ballistic-Missile and Space Program: An Assessment", Middle East Policy, 26 (1):31-48. Available at: https://doi.org/10.1111/mepo.12398.

Barzegar, Keyhan. 2010. "Iran's foreign policy strategy after Saddam", The Washington Quarterly, 33 (1): 173-189. Available at: https://doi.org/10.1080/016366 00903430665.

Cain, Anthony C. 2002. Iran's Strategic Culture and Weapons of Mass Destruction. Alabama: Air University Press.

Connell, Michael. 2010. "Iran's Military Doctrine”, The Iran Primer. Washington: US Institute of Peace. Available at: https://cutt.ly/jzDaxLk.

Eisenstadt, Michael. 2011. The Strategic Culture of the Islamic Republic of Iran: Operational and Policy Implications. MES Monographs, 1. Middle East Studies, Marine Corps University.

Eisenstadt, Michael. 2015. The strategic culture of the Islamic Republic of Iran: religion, expediency, and soft power in an era of disruptive change. Washington Institute for Near East Policy. Available at: https://cutt.ly/9zDaIm1.

Eslami, Mohammad and Alena V. G. Vieira. 2021. "Iran's strategic culture: the 'revolutionary' and 'moderation' narratives on the ballistic missile programme", Third World Quarterly, 42 (2): 312-328. Available at: https://dx.doi.org/10.1080/0143 6597.2020 .1813562$.

Firuzabadi, Seyyed J. 2014. "Moderation discourse in the foreign policy of the Islamic Republic of Iran", Strategic Policy Research, 5 (19): 43-73 (published in Persian).

Giles, Gregory F. 2003. "The crucible of radical Islam: Iran's leaders and strategic culture". In Barry R. Schneider and Jerrold M. Post (eds.), Know Thy Enemy: Profiles of Adversary Leaders and Their Strategic Cultures. Alabama: USAF Counter Proliferation Center.

Gray, Colin. S. 1999. "Strategic culture as context: the first generation of theory strikes back", Review of International Studies, 25 (1): 49-69.

Haynes, Jeffery. 2008. "Religion and foreign policy making in the USA, India and Iran: towards a research agenda", Third World Quarterly, 29 (1): 143-165. Available at: https://doi.org/10.1080/01436590701739668.

Izewicz, Paula. 2017. Iran's Ballistic Missile Program: Its Status and the Way Forward. Non-Proliferation Paper, no. 57. SIPRI EU Non-Proliferation Consortium. 
Kartchner, Kerry and Jennie Johnson. 2009. Strategic culture and weapons of mass destruction: culturally based insights into comparative national security policymaking. London: Palgrave Macmillan.

Katzman, Kenneth. 2015. Iran's foreign policy. Library of Congress, Congressional Research Service. Available at: https://cutt.ly/XzDsp23.

Katzman, Kenneth. 2017. Iran's Foreign and Defense Policies. Library of Congress, Congressional Research Service. Available at: https://apps.dtic.mil/sti/pdfs/AD1027350.pdf.

Kinch, Penelope. 2016. The US-Iran Relationship: The Impact of Political Identity on Foreign Policy. London: Bloomsbury Publishing. Available at: https://doi. org/10.5040/9781350989368.

Knepper, Jennifer. 2008. "Nuclear Weapons and Iranian strategic culture", Comparative Strategy, 27 (5): 451-468. Available at: https://doi.org/10.1080/0149593 0802430080 .

Kroenig, Matthew. 2018. "The return to the pressure track: The trump administration and the Iran nuclear deal", Diplomacy and Statecraft, 29 (1): 94-104. Available at: https://dx.doi.org/10.1080/09592296.2017.1420529.

Lantis, Jeffery S. 2002. "Strategic culture and national security policy", International Studies Review, 4 (3): 87-113. Available at: https://doi.org/10.1111/1521-9488. t01-1-00266.

Larsen, Jeffrey A. and Jeannie L. Johnson 2006. Comparative strategic cultures curriculum project: assessing strategic culture as a methodological approach to understanding WMD decision-making by states and non-state actors. Prepared for: Defense Threat Reduction Agency, Advanced Systems and Concepts Office. Available at: https:// doi.org/10.21236/ADA521640.

Mazaheri, Mohammad. 2013. "Government, Identity and Foreign Policy in Contemporary Iran”, Strategic Policy Studies, 2 (7): 125-146 (published in Persian).

Meyer, Christopher. O. 2005. "Convergence Towards a European Strategic Culture? A Constructivist Framework for Explaining Changing Norm”, European Journal of International Relations, 11 (4): 523-549. Available at: https://doi.org/ $10.1177 / 1354066105057899$.

McInnis, J. Matthew. 2017. Iranian Concepts of Warfare: Understanding Tehran's Evolving Military Doctrines. American Enterprise Institute. Available at: https:// cutt.ly/ZzDsM9d.

Miskimmon, Alister, Ben O’loughlin and Laura Roselle. 2014. Strategic Narratives: Communication Power and the New World Order. London: Routledge. Available at: https://doi.org/10.4324/9781315871264.

Murray, Williamson and Kevin M. Woods. 2014. The Iran-Iraq War: A military and strategic history. Cambridge: Cambridge University Press.

Olson, Eelik. A. 2016. "Iran's Path Dependent Military Doctrine”, Strategic Studies Quarterly, 10 (2): 63-93.

Ostovar, Afshon. 2016. Sectarian dilemmas in Iranian foreign policy: when strategy and identity politics collide. Carnegie Endowment for International Peace. Available at: https://carnegieendowment.org/files/CP_288_Brief-Ostovar-Sectarianism.pdf. 
Przeczek, Sermin. 2013. “Iran's foreign policy under president Rouhani: Pledges versus reality", Middle Eastern Analysis/Ortadogu Analiz, 5 (57): 64-71.

Perthes, Volker. 2010. "Ambition and fear: Iran's foreign policy and nuclear programme", Survival, 52 (3): 95-114. Available at: https://doi.org/10.1080/003 96338.2010.494879.

Pompeo, Mick. R. 2018. "Confronting Iran: The Trump Administration's Strategy", Foreign Affairs, November-December: 60-97.

Ramazani, Reza. K. 2004. "Ideology and pragmatism in Iran's foreign policy", The Middle East Journal, 58 (4): 1-11 (published in Persian). Available at: https://doi. org/10.3751/194034604783997123.

Salehian, Saeed. 2018. "Social resources of foreign policy of the Islamic Republic of Iran”. Policy Studies Strategic Studies. 8 (26): 165-186 (published in Persian).

Smith, Ben. 2012. "Is Iran developing a nuclear weapon?", International Affairs and Defense Section, 6 (18): 7-14.

Stanley, Willis. 2006. "The strategic culture of the Islamic Republic of Iran". In A. Larsen (ed.), Comparative strategic culture syllabus. London: Palgrave Macmillan.

Strain, Frederick R. 1996. Discerning Iran's Nuclear Strategy: An Examination of Motivations, Strategic Culture, and Rationality. War College, Air University.

Taremi, Kamran. 2014. "Iranian Strategic Culture: The Impact of Ayatollah Khomeini's Interpretation of Shiite Islam". Contemporary Security Policy, 35 (1): 3-25. Available at: https://doi.org/10.1080/13523260.2014.884341.

Thaler, David E., Alireza Nader, Shahram Chubin, Charlotte Lynch and Jerrold D. Green. 2010. Mullahs, Guards, and Bonyads: an exploration of Iranian leadership dynamics. Santa Monica: Rand Corporation. Available at: https://doi.org/10.7249/MG878.

Ward, Steven. R. 2005. "The continuing evolution of Iran's military doctrine", The Middle EastJournal, 59 (4):559-576. Availableat: https://doi.org/10.3751/59.4.12. Yossef, Amr. 2019. "Upgrading Iran's Military Doctrine: An Offensive 'Forward Defense"”. The Middle East Institute, 10. Available at: https://cutt.ly/IzDfPQw.

Appendix 1.

AfFILIATION AND POSITION OF INVESTIGATED NARRATORS

\begin{tabular}{ll}
\hline Narrator & Affiliation \\
\hline Abbasi & Former IRGC general and University professor \\
\hline Alamal-Hoda & Imam of Friday Prayers in Mashhad \\
\hline Amouei & Member of Parliament \\
\hline Ashena & President's advisor \\
\hline Khamenei & Supreme Leader \\
\hline Bagheri & Chief of the staff for armed forces \\
\hline Esmaeeli & Speaker of Judiciary power \\
\hline Dadras & Deputy commander of Army \\
\hline
\end{tabular}




\begin{tabular}{ll}
../... & \\
\hline Narrator & Affiliation \\
\hline Dehghan & Military advisor of Supreme Leader \\
\hline Ghadi & Supreme leader's representative in Mashhad \\
\hline GHalibaf & Head of Quds IRGC (after Soleimani) \\
\hline Hajizadeh & Parliament's President \\
\hline Jafari & Commander of IRGC's Aerospace forces \\
\hline Kamalvandi & Former Head of IRGC \\
\hline Kavakebian & Speaker of atomic energy organization \\
\hline Lahouti & Member of Parliament \\
\hline Maleki & Member of Parliament \\
\hline Motahari & Member of Parliament \\
\hline Mousavi, A & Parliament's Vice President \\
\hline Mousavi, $\mathbf{M}$ & Speaker of the ministry of foreign affairs \\
\hline Naghdi & Deputy commander of IRGC air-space forces \\
\hline Nobakht & IRGC Speaker \\
\hline Pezeshkian & Former Speaker of Iran's Government \\
\hline Raeesi & Parliament's Vice President \\
\hline Raefi-pour & Chief Justice of Iran \\
\hline Rahimpour & University professor and public figure \\
\hline Rezaee & University professor and public figure \\
\hline Rouhani & Former Head of IRGC, Military consulate of Supreme Leader \\
\hline Salehi & President \\
\hline Seddighi & Head of atomic energy organization \\
\hline Tajzadeh & Imam of Friday Prayers of Tehran \\
\hline Zarif & Former advisor of president \\
\hline Consulate of Supreme Leader in foreign Affairs \\
\hline Fiba-kalam & University professor and public figure \\
\hline
\end{tabular}

Source: Own elaboration.

Presented for evaluation: July $27^{\text {th }}, 2020$.

Accepted for publication: March $3^{\text {rd }}, 2021$.

\section{MOHAMMAD ESLAMI}

ID7418@alunos.uminho.pt

ORCID: 0000-0003-0283-1839.

Collaborative researcher of the Research Centre for Political Science (CICP) at the department of Political Science and International Relations at the University of 
Minho (Portugal). His Ph.D. dissertation is entitled "Strategic Culture and the Foreign Policy of the Islamic Republic of Iran: Assessing the Ballistic Missiles and Unmanned Combat Aerial Vehicles programme" and has been supervised by Professor Alena Vieira (University of Minho) and Professor Arshin Adib-Moghaddam ((SOAS) University of London). He holds a B.A. Degree in Arab Studies, and a master's degree in political science and International Relations. His research interests are primarily related to Middle East Studies, Security Studies, Arms Control, and Iranian Studies. 